\title{
STABILITY-INDICATING RP-HPLC METHOD FOR SIMULTANEOUS DETERMINATION OF METHOXSALEN AND $p$-AMINOBENZOIC ACID IN BINARY COMBINATION
}

\author{
Peter John ${ }^{1 *}$, Waqar Azeem ${ }^{1}$, Muhammad Ashfaq ${ }^{2 *}$, Islam Ullah Khan ${ }^{1}$, Syed Naeem Razzaq ${ }^{1}$ \\ and Salah Ud-Din Khan ${ }^{3}$ \\ ${ }^{1}$ Department of Chemistry, Government College University, Lahore-54000, Pakistan \\ ${ }^{2}$ Department of Chemistry, H. H. Campus, University of Gujrat, Gujrat-50700, Pakistan \\ ${ }^{3}$ Deanship of Scientific Research, College of Engineering, King Saud University, Riyadh 11421, \\ Saudi Arabia
}

(Received January 28, 2014; revised October 1, 2014)

\begin{abstract}
An accurate, simple and specific reverse phase LC procedure is established and validated for simultaneous estimation of methoxsalen and $p$-aminobenzoic acid in pharmaceutical formulated products and human serum. Chromatographic separation among methoxsalen, $p$-aminobenzoic acid and their degradation products have been achieved in less than $5 \mathrm{~min}$ with Hypersil-ODS column $(250 \mathrm{~mm} \times 4.6 \mathrm{~mm}, 5 \mu \mathrm{m})$, using acetonitrile and $1.28 \mathrm{mM}$ phosphate buffer as mobile phase $(60: 40 \mathrm{v} / \mathrm{v})$. Flow rate of the mobile phase was set as $1.5 \mathrm{~mL} \mathrm{~min}^{-1}$ and detection of all the analytes was carried out by diode-array detector at $254 \mathrm{~nm}$. The developed method was validated according to ICH guidelines by performing its linearity, accuracy, precision, specificity, robustness and LOD/LOQ values. Response was linear and proportional to the concentrations $\left(24-48 \mu \mathrm{g} \mathrm{mL}^{-1}\right)$ for p-aminobenzoic acid and $\left(9-18 \mu \mathrm{g} \mathrm{mL}^{-1}\right)$ for methoxsalen. The LOD was $2.3 \mathrm{ng} \mathrm{mL}^{-1}$ for $p$-aminobenzoic acid and $6 \mathrm{ng} \mathrm{mL}{ }^{-1}$ for methoxsalen whereas LOQ was $7.8 \mathrm{ng} \mathrm{mL}^{-1}$ for $p$-aminobenzoic acid and $20.4 \mathrm{ng} \mathrm{mL}^{-1}$ for methoxsalen. The developed method efficiently separated the principal peaks from degradation products and therefore can be applied successfully for concurrent analysis of methoxsalen and $p$-aminobenzoic acid in pharmaceutical dosage form, human serum and product stability studies.
\end{abstract}

KEY WORDS: $p$-Aminobenzoic acid, Methoxsalen, Degradation products

\section{INTRODUCTION}

Methoxsalen is chemically designated as 9-methoxy-7H-furo-(3,2-g)-1-benzopyran (7) one. It is a photosensitizer that greatly increases the skin reactivity to long wavelength ultraviolet radiations $(320$ to $400 \mathrm{~nm})$. It is indicated for the treatment of psoriasis, eczema and to repigment the vitiliginous areas of the skin in conjunction with controlled doses of ultraviolet $\mathrm{A}$ $(320-400 \mathrm{~nm})$ or sunlight. $p$-Aminobenzoic acid is chemically designated as 4-aminobenzoic acid (Figure 1). It is applied topically on the skin as sunscreen. Aminobenzoic acid and its derivatives absorb light effectively in the UV-B region but absorb very small or almost no UVA light [1]. Various analytical procedures for methoxsalen and $p$-aminobenzoic acid have been reported either alone or in combination with other drugs. Methoxsalen has been determined by HPLC [2-4] and by LC-MS [5-6]. The reported methods were used to analyze methoxsalen only and its simultaneous determination with $p$-aminobenzoic acid was not carried out. In addition the LC-MS methods cannot be used in ordinary laboratories due to unavailability. Jyothi et al. [7] have recently published an HPLC method for the determination of methoxsalen in dosage form by HPLC. Although the retention time of methoxsalen was less than $4.5 \mathrm{~min}$, the method does not involve the forced degradation studies which make it unsuitable for stability monitoring. The analytical techniques that had been reported for $p$-aminobenzoic acid included determination by high performance liquid chromatography [8-9], spectrophotometry [10-11] and titrimetry [12]. Kumar et al. [13] have analysed p-aminobenzoic acid in multivitamin dosage

*Corresponding author. E-mail: ashfaqchemist@hotmail.com, peterjohn@gcu.edu.pk 
forms. The separation of methoxsalen occurs in about 13 min but there was not forced degradation studies involved.

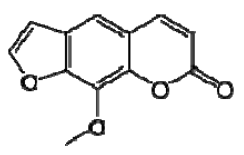

(A)

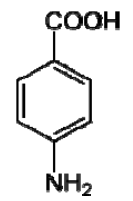

(B)

Figure 1. Methoxsalen (A) and p-aminobenzoic acid (B).

The combination of methoxsalen and p-aminobenzoic acid is approved and available in the market on prescription. However, this combination product is not included in any pharmacopoeia like EP, USP, and JP. In addition to absence of any HPLC methods in the pharmacopoeia, a careful and thorough literature review also showed absence of any reversed phase LC method for simultaneous estimation of both drugs in dosage formulations and human serum. Reverse phase chromatography is preferred over normal phase in pharmaceutical analysis as most of the drugs can be retained by this phase. In addition water is used in reverse phase chromatography which is also an advantage [14]. The purpose of stability testing is to check the drug quality under the action of many environmental factors like temperature, acid, base and oxidative condition. This is necessary for establishment of re-test period for the drug products and for recommendation conditions for their storage. ICH guidelines therefore emphasize stability-indicating analytical methods [15]. Efforts were therefore made to develop a novel, fast and validated stability indicating HPLC procedure for determining simultaneously both the drugs in pharmaceutical dosage forms and human serum. Currently we are developing analytical methods for drugs in binary combinations [16-24] and this study is a continuation of the previous work as it contained two active ingredients in formulation.

\section{EXPERIMENTAL}

\section{Chemicals and reagents}

Working standards of p-aminobenzoic acid (99.8\% purity) and methoxsalen $(99.5 \%$ purity) were from Lahore Chemical \& Pharmaceutical Works (Pvt) Ltd., (Lahore, Pakistan). Acetonitrile of HPLC grade, sodium hydroxide, potassium-dihydrogen phosphate, $\mathrm{HCl}$ and potassium permanganate (analytical grade, Fluka UK origin) were procured from the Central Chemicals Lahore, Pakistan. Water used during method development and validation was double distilled. Solutions were filtered from $0.45 \mu \mathrm{m}$ nylon filters from Sartorius (Germany).

\section{System conditions}

The liquid chromatograph utilized was of Shimadzu (Japan), model LC-20A. The system was equipped with pump LC-20AT and a diode array detector SPD-M20A. The detector was adjusted at $254 \mathrm{~nm}$. The system was fitted with a manual injector (Rheodyne valve) having a loop of $20 \mu \mathrm{L}$. Separations were achieved with Hypersil-ODS stationary phase $(250 \times 4.6 \mathrm{~mm}, 5$ $\mu \mathrm{m})$. Mobile phase comprised of acetonitrile and $1.28 \mathrm{mM}$ potassium dihydrogen phosphate buffer in 60:40 (v/v). Solutions were degassed using Elma-sonic E30H (Germany) before analysis. Mobile phase was delivered at $1.5 \mathrm{~mL} \mathrm{~min}^{-1}$. 
RP-HPLC method for simultaneous determination of methoxsalen and $p$-aminobenzoic acid 29

Preparation of stock standard solution (A)

For standard stock solution (A) of p-aminobenzoic acid and methoxsalen, $100 \mathrm{mg} p$-aminobenzoic acid and $37.5 \mathrm{mg}$ methoxsalen were taken in $100 \mathrm{~mL}$ flask. Volume was completed to the mark with mobile phase. Final solution was sonicated for $10 \mathrm{~min}$ to obtain final concentration equivalent to $1000 \mu \mathrm{g} \mathrm{mL} L^{-1}$ of $p$-aminobenzoic acid and $375 \mu \mathrm{g} \mathrm{mL} L^{-1}$ of methoxsalen.

Preparation of working standard solution (B)

A $2 \mathrm{~mL}$ aliquot of stock standard solution (A) was transferred into a $50 \mathrm{~mL}$ flask. The volume was adjusted to mark with mobile phase. The prepared final working standard solution (B) contained $40 \mu \mathrm{g} \mathrm{mL}^{-1} p$-aminobenzoic acid and $15 \mu \mathrm{g} \mathrm{mL}^{-1}$ methoxsalen. Before analysis, the solution was filtered through nylon filter $(0.45 \mu \mathrm{m})$.

\section{Preparation of ointment sample solution}

Accurately weighed $1 \mathrm{~g}$ of the ointment equivalent to $20 \mathrm{mg}$ of $p$-aminobenzoic acid and $7.5 \mathrm{mg}$ methoxsalen was taken in $100 \mathrm{~mL}$ flask. Approximately $50 \mathrm{~mL}$ mobile phase was added, warmed up to $40{ }^{\circ} \mathrm{C}$ and shaken well to dissolve. Volume was adjusted to the mark with mobile phase. $5 \mathrm{~mL}$ of above solution was diluted to $25 \mathrm{~mL}$ with mobile phase to get $40 \mu \mathrm{g} \mathrm{mL}^{-1}$ of $p$ aminobenzoic acid and $15 \mu \mathrm{g} \mathrm{mL}^{-1}$ methoxsalen. Before analysis, the solution was filtered through nylon filter $(0.45 \mu \mathrm{m})$.

\section{Human serum sample preparation}

Serum samples were injected directly into HPLC system after protein precipitation. For preparation of serum sample, $1 \mathrm{~mL}$ of human serum was spiked with $1 \mathrm{~mL}$ of stock solution (A) in polypropylene centrifuge tube. Then $24 \mathrm{~mL}$ of acetonitrile was added and the mixture centrifuged at $10,000 \mathrm{rpm}$ for $8-10 \mathrm{~min}$ to precipitate proteins. The volume of acetonitrile used was for precipitation as well as for dilution purpose. Final concentration of solution obtained was equivalent to $40 \mu \mathrm{g} \mathrm{mL}^{-1}$ of $p$-aminobenzoic acid and $15 \mu \mathrm{g} \mathrm{mL}^{-1}$ of methoxsalen. The supernatant was collected in polypropylene tube. Before analysis, the solution was filtered through nylon filter $(0.45 \mu \mathrm{m})$.

\section{Method linearity}

For the proposed method linear graphs were attained in the concentration range of 24-48 $\mu \mathrm{g}$ $\mathrm{mL}^{-1}\left(24,28,32,36,40,44,48 \mu \mathrm{g} \mathrm{mL}^{-1}\right)$ for $p$-aminobenzoic acid and 9-18 $\mu \mathrm{g} \mathrm{mL}^{-1}(9,10.5,12$, $\left.13.5,15,16.5,18 \mu \mathrm{g} \mathrm{mL} \mathrm{m}^{-1}\right)$ for methoxsalen. Three solutions were prepared for each concentration and analyzed.

\section{Method accuracy}

Accuracy was estimated by the analysis of synthetic mixtures of $p$-aminobenzoic acidmethoxsalen in dosage form and serum. Declared amounts of methoxsalen and $p$-aminobenzoic acid of declared purity were spiked into placebo components (hard paraffin, bee's wax, cetostearyl alcohol, petroleum jelly) of the ointment and human serum. Synthetic mixture (100 $\%$ nominal analytical concentration) of $p$-aminobenzoic acid $\left(40 \mu \mathrm{g} \mathrm{mL}^{-1}\right)$ and methoxsalen $(15$

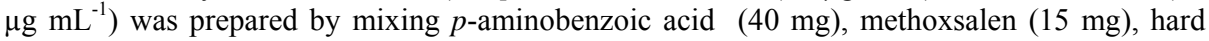
paraffin $(55 \mathrm{mg})$, bee's wax $(38 \mathrm{mg})$, cetostearyl alcohol $(92.2 \mathrm{mg})$ and petroleum jelly $(1.75 \mathrm{~g})$. Three concentrations ranging from 50 to $150 \%$ of the nominal analyte concentration were made and analyzed by the developed method. 


\section{Method precision}

Inter-day as well as intra-day precision methodology was utilized to demonstrate the repeatability of the proposed method. In intra-day methodology five standard solutions (three dissimilar concentrations) of $p$-aminobenzoic acid and methoxsalen were injected into HPLC system in single day. In inter-day precision the same solutions were injected for three consecutive (un-interrupted) days. To express the precision, RSD \% of the $p$-aminobenzoic acid and methoxsalen peaks was calculated.

\section{Stress induced studies (specificity)}

Specificity test was conducted according to different ICH stated stress situations [25]. ICH stresses to include tests of samples under relevant stress conditions: light, heat, humidity, acid/base hydrolysis and oxidation.

\section{Acid-stress studies}

Acid stress studies were carried out at $40{ }^{\circ} \mathrm{C}$ and relative humidity (RH) $75 \%$ in an environmental accelerated chamber using $5 \mathrm{M}$ hydrochloric acid. For these studies $4 \mathrm{~mL}$ stock standard solution (A) was transferred to $100 \mathrm{~mL}$ flask. $4 \mathrm{~mL}$ of $5 \mathrm{M}$ hydrochloric acid then added into the flask and placed at $40^{\circ} \mathrm{C} / 75 \% \mathrm{RH}$ in the environmental accelerated chamber for half an hour. After completion of the stress studies, about $4 \mathrm{~mL}$ of $5 \mathrm{M}$ sodium hydroxide was added to neutralize the solution. Volume was adjusted to mark using mobile phase.

\section{Base-stress studies}

Basic stress degradations studies were carried out using $5 \mathrm{M}$ sodium hydroxide at $40{ }^{\circ} \mathrm{C}$ and $75 \%$ RH. In a volumetric flask of $100 \mathrm{~mL}, 4 \mathrm{~mL}$ stock standard solution (A) and $4 \mathrm{~mL}$ of $5 \mathrm{M}$ sodium hydroxide were mixed and the flask placed at $40{ }^{\circ} \mathrm{C} / 75 \% \mathrm{RH}$ for $10 \mathrm{~min}$. After completion of the stress studies, about $4 \mathrm{~mL}$ of $5 \mathrm{M}$ hydrochloric acid was added to neutralize the solution. The volume was adjusted to mark using mobile phase.

\section{Oxidative-stress studies}

These studies were conducted at room temperature using $0.001 \% \mathrm{KMnO}_{4}$ solution. $4 \mathrm{~mL}$ of stock standard solution was transferred to a $100 \mathrm{~mL}$ flask and mixed with $4 \mathrm{~mL}$ of $0.001 \%$ $\mathrm{KMnO}_{4}$. The flask was allowed to stand at room temperature for $20 \mathrm{~min}$. After completion of the stress studies mobile phase was added to the mark. This solution was then injected in to the HPLC system.

\section{Photolytic-stress studies}

$4 \mathrm{~mL}$ stock standard solution (A) was transferred into $100 \mathrm{~mL}$ flask. The flask was then placed in open sunlight for 4 hours. After that, mobile phase was added to the mark. This solution was then injected in to the HPLC system.

\section{$U V$-stress studies}

For the UV degradation studies, $4 \mathrm{~mL}$ of the stock standard solution was transferred into a 100 $\mathrm{mL}$ flask and placed under UV light for 4 days. This solution was then injected in to the HPLC system. 
RP-HPLC method for simultaneous determination of methoxsalen and $p$-aminobenzoic acid 31

\section{Thermal-stress studies}

A $4 \mathrm{~mL}$ portion of the stock standard solution was transferred to $100 \mathrm{~mL}$ flask and placed over hot plate for 2 hours at $160{ }^{\circ} \mathrm{C}$. After $2 \mathrm{~h}$, mobile phase was added to the mark. This solution was then injected in to the HPLC system.

\section{Robustness}

Deliberate changes were made in the experimental conditions to assess the robustness of the developed method. For this intention, slight changes were made in $\mathrm{pH}$ of buffer solution (5.4 to 5.6), composition (acetonitrile: $\mathrm{KH}_{2} \mathrm{PO}_{4} 58: 42 \mathrm{v} / \mathrm{v}$ to $62: 38 \mathrm{v} / \mathrm{v}$ by an increment of $2 \mathrm{~mL}$ of acetonitrile each time) as well as flow rate $\left(1.4\right.$ to $\left.1.6 \mathrm{~mL} \mathrm{~min}^{-1}\right)$ of the mobile phase. The effects of these changes on chromatographic parameters of retention time, theoretical plates, resolution and tailing factor were noted.

\section{Detection and quantitation limits}

Signal/noise $(\mathrm{S} / \mathrm{N})$ ratio method was used to calculate the LOD and LOQ values. For this purpose, solution concentrations were prepared in descending order by way of spiking known concentrations of $p$-aminobenzoic acid and methoxsalen into drug excipients (placebo) and human serum. The solutions were made by the defined protocol and repeatedly analysed to find $\mathrm{S} / \mathrm{N}$ ratio. The average ratio at each level of concentration was used to determine the detection and quantitation limits. The lowest concentration of $p$-aminobenzoic acid and methoxsalen which gives 10:1 signal to noise ratio where $p$-aminobenzoic acid and methoxsalen can be quantitated with accuracy was represented as LOQ and the lowest level of concentration which gives 3:1 signal to noise ratiowhere $p$-aminobenzoic acid and methoxsalen can be detected was expressed as detection limit.

\section{RESULTS AND DISCUSSIONS}

The purpose of this study was to develop a simple, fast and economic stability indicating high performance LC method for the instant and simultaneous determination of $p$-aminobenzoic acid and methoxsalen in combination form. In order to accomplish this goal, chromatographic conditions were optimized. For optimization of conditions and to acquire symmetrical sharp peaks, different organic solvents and buffers with varied $\mathrm{pH}$ range in different proportions were tried in order to optimize the mobile phase composition. In addition, four different stationary phases (Hypersil-100 C18, Hypersil-ODS, Hypersil-BDS C18, and Hypersil-BDS C8) were initially chosen for optimization of stationary phase.

\section{Optimizing mobile and stationary phases}

Composition of mobile phase was studied systematically through a series of experiments to obtain symmetrical peaks of $p$-aminobenzoic acid and methoxsalen. Different volume ratios $(80: 20,60: 40,40: 60,20: 80)$ of methanol and water were tested and various columns (Hypersil100 C18, Hypersil-ODS, Hypersil-BDS C18, Hypersil-BDS C8) used to obtain best resolution and separations but $p$-aminobenzoic acid and methoxsalen showed peak broadening and asymmetry on all stationary phases. Hypersil ODS column provided almost symmetrical peak of $p$-aminobenzoic acid (tailing factor 1.53 with retention time 6.48 ) and asymmetrical peak of methoxsalen with long retention time (tailing factor 2.1 and retention time 9.65). Increasing column temperature to $45^{\circ} \mathrm{C}$ did not improve the symmetry and long retentions of methoxsalen. Asymmetrical peaks of $p$-aminobenzoic acid and methoxsalen might be due to the interaction of oxygen atoms of the methoxsalen and the acidic (carboxylic) group of carbon-1 and amino 
group of the carbon- 4 of the $p$-aminobenzoic acid with the silanol groups of the stationary phase or metal ion impurities present in the column. In order to avoid these problems, methanol was replaced by acetonitrile and water by $1.28 \mathrm{mM}$ potassium dihydrogen phosphate buffer ( $\mathrm{pH} 5.5)$. Highly sharp and symmetrical peaks of $p$-aminobenzoic acid and methoxsalen were obtained with acetonitrile and $1.28 \mathrm{mM}$ phosphate buffer $(60: 40 \mathrm{v} / \mathrm{v})$ on Hypersil-ODS column in contrast to the other stationary phases like Hypersil-100 C18, Hypersil-ODS, Hypersil-BDS C18, Hypersil-BDS C8 (All $250 \times 4.6 \mathrm{~mm}, 5 \mu \mathrm{m})$ with better peak shape, theoretical plates and resolution (Figure 2).

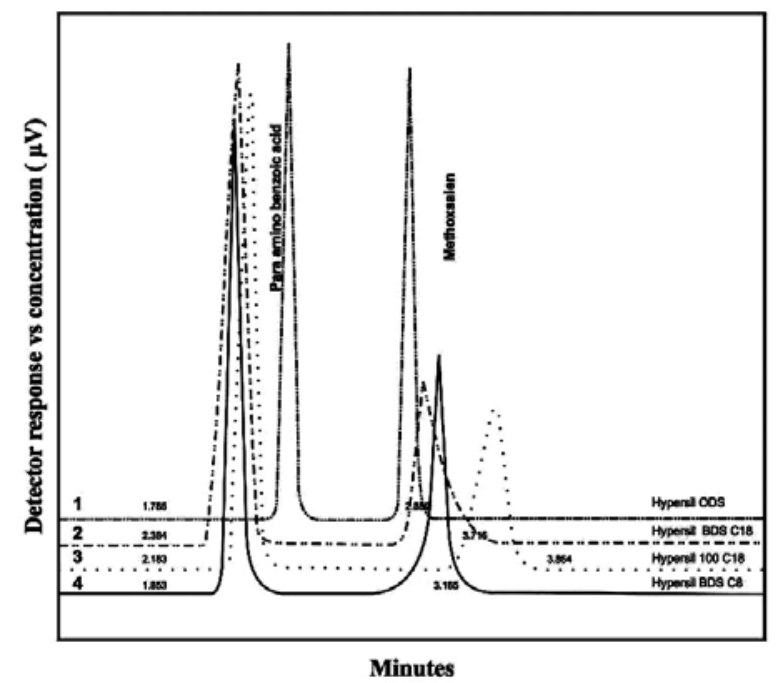

Figure 2. Chromatograms of $p$-aminobenzoic acid and methoxsalen on various stationary phases (1) chromatogram of $p$-aminobenzoic acid and methoxsalen on Hypersil ODS column, (2) chromatogram of $p$-aminobenzoic acid and methoxsalen on Hypersil BDS C18 column, (3) chromatogram of $p$-aminobenzoic acid and methoxsalen on Hypersil 100 C18 column, (4) chromatogram of $p$-aminobenzoic acid and methoxsalen on Hypersil BDS C18 column.

Optimization of the $\mathrm{pH}$ of the phosphate buffer

For optimizing suitable $\mathrm{pH}$ of the phosphate buffer, a series of trials were carried out at different $\mathrm{pH}$ values $(3.0,4.0,5.5$ and 6.5$)$ of buffer solutions. This range was chosen as RP-columns are generally limited to almost this $\mathrm{pH}$ range (2-8). Hypersil ODS stationary phase was used for optimizing suitable $\mathrm{pH}$ value. This $\mathrm{pH}$ effect on the elution of both the components is shown in (Figure 3). Sharp and symmetrical peaks of the $p$-aminobenzoic acid and methoxsalen were obtained at pH 5.5 using acetonitrile and $1.28 \mathrm{mM}$ phosphate buffer $(60: 40 \mathrm{v} / \mathrm{v})$, with reasonable number of theoretical plates, good resolution and acceptable tailing (Table 1). Finally (60:40 $\mathrm{v} / \mathrm{v}$ ) acetonitrile and $1.28 \mathrm{mM}$ potassium dihydrogen phosphate buffer was adopted that showed symmetrical peaks of $p$-aminobenzoic acid and methoxsalen using Hypersil ODS column at retention times of 1.78 and 2.89 of $p$-aminobenzoic acid and methoxsalen, respectively.

\section{Analytical method validation}

Validation of the proposed analytical method was conducted according to ICH guidelines [23]. Validation parameters included accuracy, precision, linearity, robustness, specificity, LOD and 
RP-HPLC method for simultaneous determination of methoxsalen and $p$-aminobenzoic acid 33

LOQ. For determination of linearity, different concentrations of $p$-aminobenzoic acid $(24,28$, 32, 36, 40, 44, $\left.48 \mu \mathrm{g} \mathrm{mL}^{-1}\right)$ and methoxsalen $\left(9,10.5,12,13.5,15,16.5,18 \mu \mathrm{g} \mathrm{mL}^{-1}\right)$ were prepared and calibration curve was drawn using peak areas. Linear regression for $p$-aminobenzoic acid was $\mathrm{Y}=131848 \mathrm{x}+402736$ whereas for methoxsalen it was $\mathrm{Y}=164071 \mathrm{x}+49485$ with the value of correlation coefficient 0.9997 and 0.9999 , respectively.

For calculation of LOD and LOQ, serial dilutions of $p$-aminobenzoic acid and methoxsalen (2.3 $\mathrm{mg} \mathrm{mL}^{-1}, 0.46 \mathrm{mg} \mathrm{mL}^{-1}, 23 \mu \mathrm{g} \mathrm{mL}^{-1}, 230 \mathrm{ng} \mathrm{mL}^{-1}$ and $2.3 \mathrm{ng} \mathrm{mL}^{-1}$ for $p$-aminobenzoic acid and $6 \mathrm{mg} \mathrm{mL}^{-1}, 1.2 \mathrm{mg} \mathrm{mL}^{-1}, 60 \mu \mathrm{g} \mathrm{mL}^{-1}, 600 \mathrm{ng} \mathrm{mL}^{-1}$ and $6 \mathrm{ng} \mathrm{mL}^{-1}$ for methoxsalen) were prepared. Limit of detection was then estimated by the concentration where $\mathrm{S} / \mathrm{N}$ ratio was $3: 1$. The LOD values calculated were $2.3 \mathrm{ng} \mathrm{mL}^{-1}$ for $p$-aminobenzoic acid and $6 \mathrm{ng} \mathrm{mL}^{-1}$ for methoxsalen. The calculated LOQ was $7.8 \mathrm{ng} \mathrm{mL}^{-1}$ for $p$-aminobenzoic acid and $20.4 \mathrm{ng} \mathrm{mL}$ for methoxsalen $(\mathrm{S} / \mathrm{N}$ ratio $10: 1)$

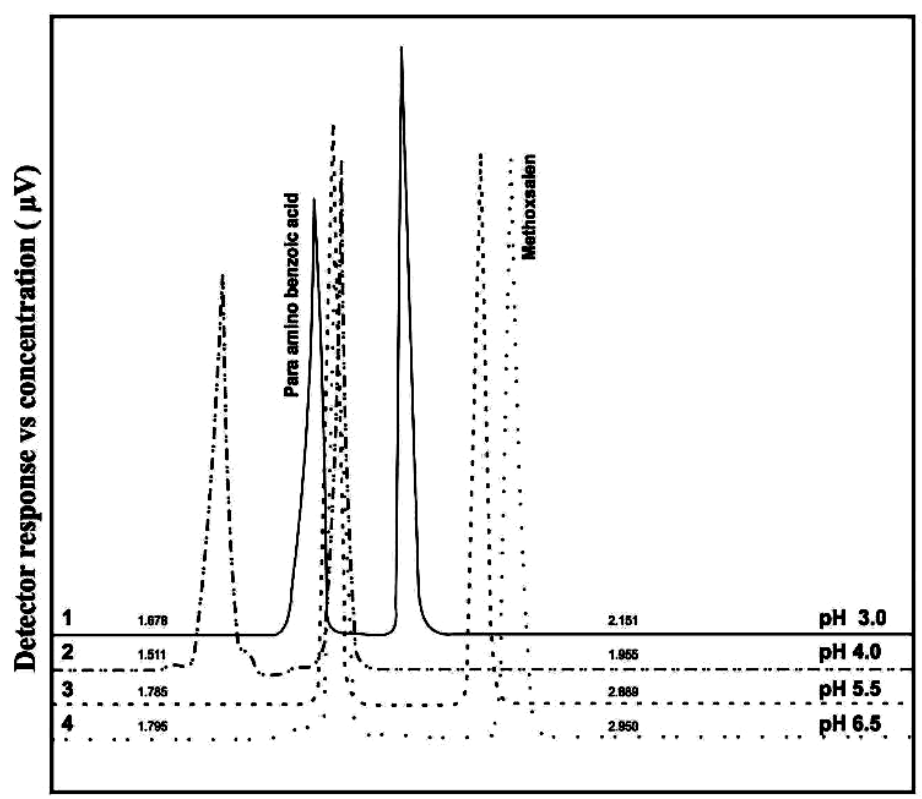

Minutes

Figure 3. Chromatograms of $p$-aminobenzoic acid and methoxsalen at different $\mathrm{pH}$ (1) chromatogram of $p$-aminobenzoic acid and methoxsalen at $\mathrm{pH} 3.0,(2)$ chromatogram of $p$-aminobenzoic acid and methoxsalen at $\mathrm{pH} 4.0$, (3) chromatogram of $p$ aminobenzoic acid and methoxsalen at $\mathrm{pH} 5.5$, (4) chromatogram of $p$-aminobenzoic acid and methoxsalen at $\mathrm{pH} 6.5$.

To check the accuracy, known amounts of methoxsalen and $p$-aminobenzoic acid were added into the sample solution containing known amounts of analytes. Results were then compared with the true values. True value was obtained by injecting the standard solutions of known concentration. Results of percentage recoveries are shown in the (Table 2). The results revealed that method is accurate and appropriate for anticipated use. The results were very close to the true value and were within the range of theoretical expected value (98-102\%). Both intraday precision and inter-day precision was performed to validate the proposed method. It was reported in term of RSD \%. The results are presented in the (Table 3). In both the cases \% RSD is less than generally accepted theoretical value $(<2 \%)$.

Bull. Chem. Soc. Ethiop. 2015, 29(1) 
Table 1. Effect of $\mathrm{pH}$ of buffer on chromatographic performance.

\begin{tabular}{|l|c|c|c|c|}
\hline Mobile phase & Theoretical plates & Tailing factor & Resolution & Peak shape \\
\hline Acetonitrile: $\mathrm{KH}_{2} \mathrm{PO}_{4} \mathrm{pH} \mathrm{3.0} \mathrm{(60:40)}$ & & & & \\
\hline p-Aminobenzoic acid & 1930 & 0.8 & & --- \\
\hline Methoxsalen & 3634 & 1.8 & 4.6 & --+ \\
\hline Acetonitrile: $\mathrm{KH}_{2} \mathrm{PO}_{4} \mathrm{pH} 4.0(60: 40)$ & & & & \\
\hline$p$-Aminobenzoic acid & 1861 & 0.70 & & --- \\
\hline Methoxsalen & 2027 & 0.70 & 1.6 & --+ \\
\hline Acetonitrile: $\mathrm{KH}_{2} \mathrm{PO}_{4} \mathrm{pH} 5.5(60: 40)$ & & & & \\
\hline p-Aminobenzoic acid & 1770 & 1.2 & & +++ \\
\hline Methoxsalen & 4649 & 1.1 & 6.5 & +++ \\
\hline Acetonitrile: $\mathrm{KH}_{2} \mathrm{PO}_{4} \mathrm{pH} 6.5(60: 40)$ & & & & \\
\hline$p$-Aminobenzoic acid & 2113 & 1.0 & & --- \\
\hline Methoxsalen & 2166 & 1.4 & 4.1 & --+ \\
\hline
\end{tabular}

+++ for symmetrical peak and --- for unsymmetrical peak.

Table 2. Accuracy results of the developed method.

\begin{tabular}{|c|c|c|c|}
\hline Nature of sample & $\begin{array}{c}\text { Concentrations spiked } \\
\left(\mu \mathrm{g} \mathrm{mL}^{-1}\right)\end{array}$ & $\begin{array}{c}\text { Measured concentration } \\
\left(\mu \mathrm{g} \mathrm{mL}^{-1}\right) \pm \mathrm{RSD}(\%)\end{array}$ & Recovery (\%) \\
\hline \multicolumn{4}{|c|}{ Pharmaceutical ointment } \\
\hline & 80 & $80.1 \pm 0.1$ & 100 \\
\hline \multirow[t]{2}{*}{$p$-Aminobenzoic acid } & 100 & $99.8 \pm 0.1$ & 99.8 \\
\hline & 120 & $120 \pm 0.1$ & 99.9 \\
\hline \multirow{3}{*}{ Methoxsalen } & 80 & $79.8 \pm 0.1$ & 99.8 \\
\hline & 100 & $99.7 \pm 0.9$ & 98.7 \\
\hline & 120 & $119 \pm 0.7$ & 99.5 \\
\hline \multicolumn{4}{|l|}{ Spiked Serum } \\
\hline \multirow{3}{*}{$p$-Aminobenzoic acid } & 80 & $79.1 \pm 0.8$ & 98.9 \\
\hline & 100 & $100 \pm 0.3$ & 100 \\
\hline & 120 & $119 \pm 1.2$ & 99.5 \\
\hline \multirow{3}{*}{ Methoxsalen } & 80 & $80.1 \pm 1.4$ & 100 \\
\hline & 100 & $99.8 \pm 0.6$ & 99.8 \\
\hline & 120 & $120 \pm 0.8$ & 99.8 \\
\hline
\end{tabular}

$\mathrm{n}=$ average of 5 analysis.

Table 3. Precision results of the developed method.

\begin{tabular}{|c|c|c|c|}
\hline Drugs & $\begin{array}{c}\text { Real } \\
\text { concentrations } \\
\left(\mu \mathrm{g} \mathrm{mL}^{-1}\right)\end{array}$ & $\begin{array}{c}\text { Intra-day precision measured } \\
\text { concentration }\left(\mu \mathrm{g} \mathrm{mL}^{-1}\right) \pm \\
\operatorname{RSD}(\%)\end{array}$ & $\begin{array}{c}\text { Inter-day precision } \\
\text { measured concentration } \\
\left(\mu \mathrm{g} \mathrm{mL}^{-1}\right) \pm \mathrm{RSD}(\%)\end{array}$ \\
\hline \multicolumn{4}{|l|}{ Pharmaceutical ointment } \\
\hline & 80 & $80.3 \pm 0.5$ & $81.4 \pm 1.3$ \\
\hline \multirow[t]{2}{*}{$p$-Aminobenzoic acid } & 100 & $100 \pm 0.8$ & $101 \pm 0.5$ \\
\hline & 120 & $122 \pm 0.8$ & $120 \pm 0.7$ \\
\hline \multirow{3}{*}{ Methoxsalen } & 80 & $80.6 \pm 1.2$ & $80.3 \pm 1.3$ \\
\hline & 100 & $99.6 \pm 0.9$ & $100 \pm 1.1$ \\
\hline & 120 & $121 \pm 1.7$ & $121 \pm 0.9$ \\
\hline \multicolumn{4}{|l|}{ Spiked serum } \\
\hline \multirow{3}{*}{$p$-Aminobenzoic acid } & 80 & $81.0 \pm 1.1$ & $80.3 \pm 1.3$ \\
\hline & 100 & $100 \pm 1.8$ & $101 \pm 1.6$ \\
\hline & 120 & $122 \pm 1.1$ & $121 \pm 1.2$ \\
\hline \multirow{3}{*}{ Methoxsalen } & 80 & $80.2 \pm 1.1$ & $81.0 \pm 1.2$ \\
\hline & 100 & $101 \pm 1.3$ & $100 \pm 1.1$ \\
\hline & 120 & $119 \pm 1.1$ & $121 \pm 1.1$ \\
\hline
\end{tabular}

$\mathrm{n}=$ average of 5 analysis. 
RP-HPLC method for simultaneous determination of methoxsalen and $p$-aminobenzoic acid 35

During robustness study, the effects of changes in chromatographic conditions on the chromatographic parameters were negligible and show that method is robust for intended use. Results are shown in (Table 4 and Table 5).

Table 4. Robustness study for $p$-aminobenzoic acid.

\begin{tabular}{|l|c|c|c|c|}
\hline Chromatographic conditions & Assay $(\%)$ & $t_{\mathrm{R}}(\mathrm{min})$ & $\begin{array}{c}\text { Theoretical } \\
\text { plates }\end{array}$ & Tailing \\
\hline Acetonitirle: $\mathrm{KH}_{2} \mathrm{PO}_{4}(62: 38)$ & 99.3 & 1.8 & 1795 & 1.2 \\
\hline Acetonitirle: $\mathrm{KH}_{2} \mathrm{PO}_{4}(60: 40)$ & 100 & 1.8 & 1986 & 1.2 \\
\hline Acetonitirle: $\mathrm{KH}_{2} \mathrm{PO}_{4}(58: 42)$ & 102 & 1.8 & 2120 & 1.2 \\
\hline Mobile phase flow $(1.4 \mathrm{~mL} / \mathrm{min})$ & 100 & 1.9 & 1890 & 1.2 \\
\hline Mobile phase flow $(1.5 \mathrm{~mL} / \mathrm{min})$ & 100 & 1.8 & 2200 & 1.2 \\
\hline Mobile phase flow $(1.6 \mathrm{~mL} / \mathrm{min})$ & 99.8 & 1.7 & 1988 & 1.2 \\
\hline Buffer $(\mathrm{pH} 5.6)$ & 97.8 & 1.8 & 1956 & 1.2 \\
\hline Buffer (pH 5.5) & 99.9 & 1.9 & 2580 & 1.2 \\
\hline Buffer (pH 5.4) & 98.3 & 2.0 & 2355 & 1.2 \\
\hline
\end{tabular}

Table 5. Robustness study for methoxsalen.

\begin{tabular}{|l|c|c|c|c|}
\hline Chromatographic conditions & Assay (\%) & $t_{\mathrm{R}}(\mathrm{min})$ & Theoretical plates & Tailing \\
\hline Acetonitirle: $\mathrm{KH}_{2} \mathrm{PO}_{4}(62: 38)$ & 99.1 & 2.9 & 4589 & 1.1 \\
\hline Acetonitirle: $\mathrm{KH}_{2} \mathrm{PO}_{4}(60: 40)$ & 101 & 2.9 & 4648 & 1.2 \\
\hline Acetonitirle: $\mathrm{KH}_{2} \mathrm{PO}_{4}(58: 42)$ & 98.0 & 2.8 & 4666 & 1.1 \\
\hline Mobile phase flow (1.4 mL/min) & 101 & 2.9 & 4989 & 1.2 \\
\hline Mobile phase flow (1.5 mL/min) & 101 & 2.9 & 4027 & 1.1 \\
\hline Mobile phase flow (1.6 mL/min) & 99.5 & 2.9 & 4256 & 1.2 \\
\hline Buffer (pH 5.6) & 98.0 & 2.9 & 4446 & 1.2 \\
\hline Buffer (pH 5.5) & 101 & 2.9 & 4027 & 1.1 \\
\hline Buffer (pH 5.4) & 98.2 & 2.8 & 4445 & 1.1 \\
\hline
\end{tabular}

Specificity was evaluated by the application of various stress tests as acidic stress, basic stress, oxidative stress, thermal stress, UV and photolytic stress to $p$-aminobenzoic acid and methoxsalen in combination form. Under these circumstances both drugs showed degradation. Typical chromatograms of basic, acidic, photolytic, oxidative and heat stresses are shown in the Figure 4, 5, 6, 7, and 8, respectively.

Results showed that under basic stress, methoxsalen is more stable than $p$-aminobenzoic acid. Under this stress condition, $p$-aminobenzoic acid was degraded up to $10.5 \%$, whereas methoxsalen was found to be stable. Under acidic stress conditions, $p$-aminobenzoic acid was degraded up to $9 \%$ and degradation of methoxsalen was $29.1 \%$. Under UV stress conditions, both drugs found to be very stable and did not degrade.

Under photolytic stress, methoxsalen degraded substantially up to $40 \%$ and $p$-aminobenzoic acid was degraded up to $12 \%$. In oxidative stress, $p$-aminobenzoic acid and methoxsalen were degraded up to $6.6 \%$ and $7.4 \%$ respectively. In thermal (dry heat) stress studies $p$-aminobenzoic acid degraded substantially up to $57.7 \%$ and methoxsalen was degraded up to $22 \%$. Degradation results are reported in (Table 6). Beside percent degradation of each drug, different numbers of impurities (degradation products) were also appeared in basic ( 2 impurities with Imp-1 as main impurity/degradation peak), acidic (1 main impurity/degradation peak), photolytic (1 major impurity/degradation peak), oxidative (1 main impurity peak), and in thermal stress ( 2 impurity peaks and Imp-2 as the main degradation peak). 


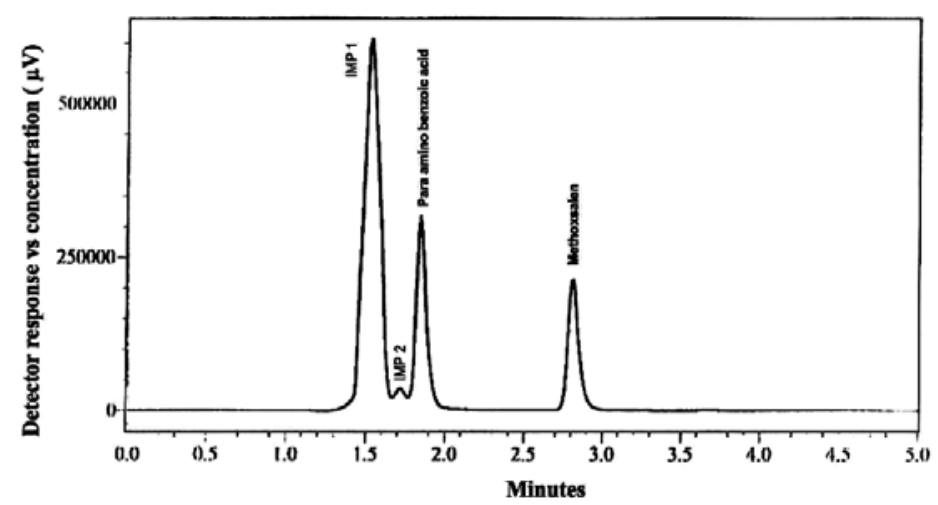

Figure 4. Chromatogram of basic stress induced degradation of $p$-aminobenzoic acid and methoxsalen.

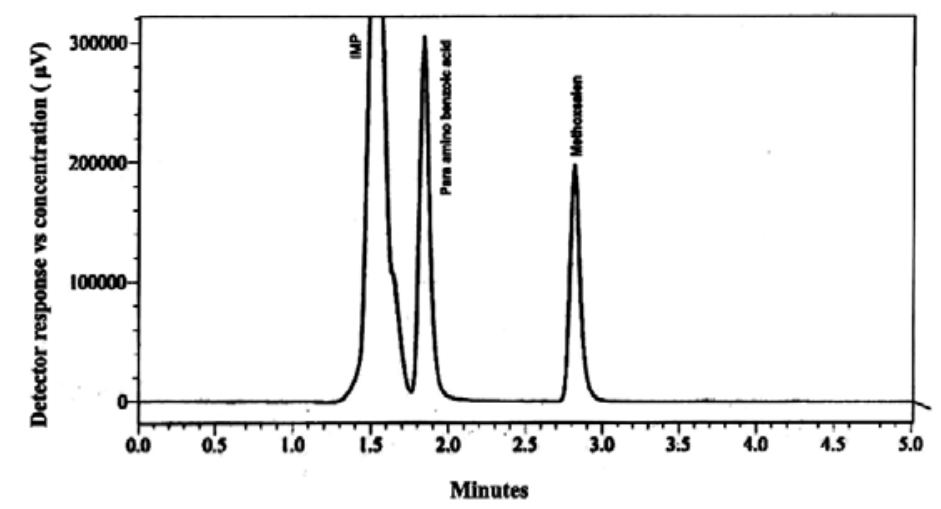

Figure 5. Chromatogram of acidic stress induced degradation of $p$-aminobenzoic acid and methoxsalen.

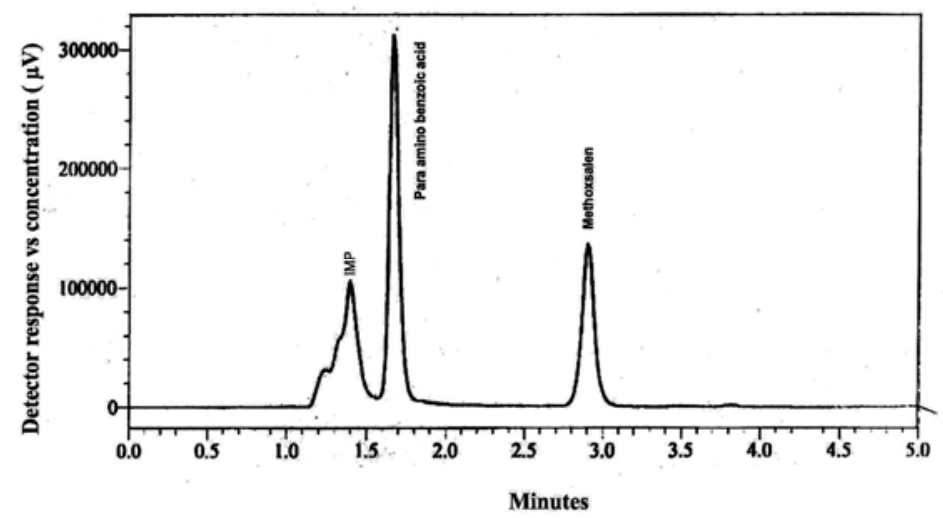

Figure 6. Chromatogram of sunlight stress induced degradation of $p$-aminobenzoic acid and methoxsalen. 
RP-HPLC method for simultaneous determination of methoxsalen and $p$-aminobenzoic acid 37

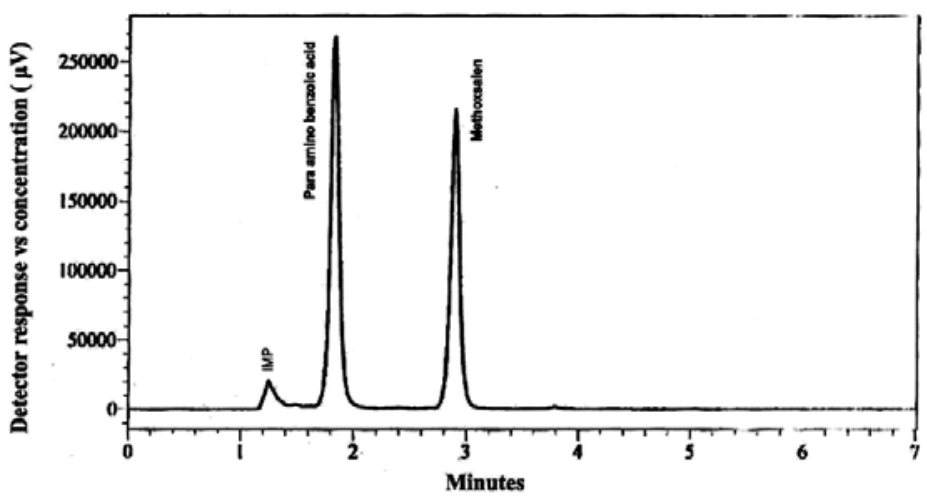

Figure 7. Chromatogram of oxidative stress induced degradation of $p$-aminobenzoic acid and methoxsalen.

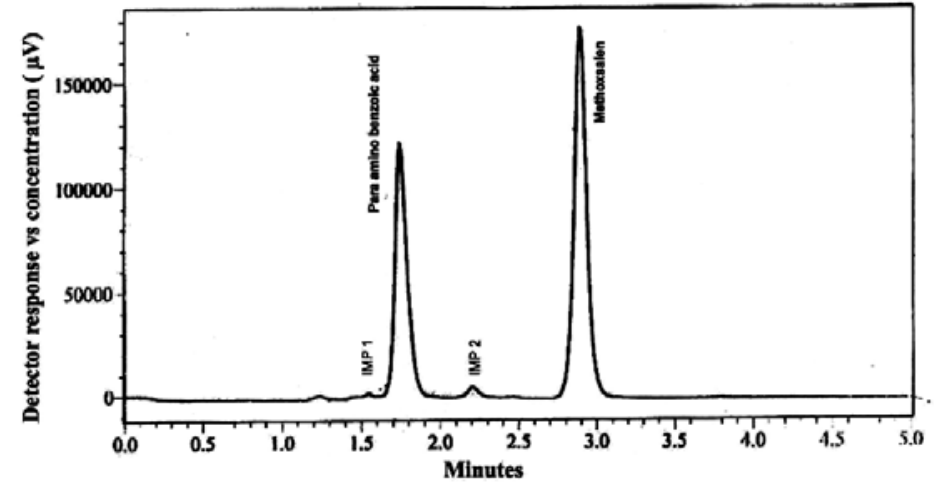

Figure 8. Chromatogram of thermal stress induced degradation of $p$-aminobenzoic acid and methoxsalen.

Table 6. Stress testing results of $p$-aminobenzoic acid and methoxsalen.

\begin{tabular}{|c|c|c|c|c|c|}
\hline Nature of stress & $\begin{array}{c}\text { Storage } \\
\text { conditions }\end{array}$ & $\begin{array}{l}\text { Time } \\
\text { (h) }\end{array}$ & $\begin{array}{l}\text { Amount of } p- \\
\text { aminobenzoic acid } \\
\text { remaining }(\%)\end{array}$ & $\begin{array}{l}\text { Amount of } \\
\text { methoxsalen } \\
\text { remaining (\%) }\end{array}$ & $\begin{array}{c}\text { Extent of } \\
\text { decomposition }\end{array}$ \\
\hline $5 \mathrm{M} \mathrm{HCl}$ & $\left(40{ }^{0} \mathrm{C}\right)$ & 0.5 & 91.1 & 70.9 & Substantial \\
\hline $5 \mathrm{M} \mathrm{NaOH}$ & $\left(40^{0} \mathrm{C}\right)$ & 0.5 & 89.5 & 97.2 & Substantial \\
\hline $0.001 \% \mathrm{KMnO}_{4}$ & $\left(25^{\circ} \mathrm{C}\right)$ & 0.5 & 93.4 & 92.6 & Substantial \\
\hline Photolytic & Sunlight & 4 & 87.9 & 59.9 & Substantial \\
\hline Ultra-Violet & UV lamp & 4 & 98.9 & 99.6 & None \\
\hline Thermal (hot plate) & $\left(160^{0} \mathrm{C}\right)$ & 4 & 42.3 & 77.9 & Substantial \\
\hline
\end{tabular}

$\mathrm{n}=$ average of 5 analysis.

Developed chromatographic method was also used for estimation of $p$-aminobenzoic acid and methoxsalen in commercially available ointment (Figure 9). The results are presented in Table 7 , which show high percent recovery and low \% RSD. 
Table 7. Assay results of $p$-aminobenzoic acid and methoxsalen in pharmaceutical ointment.

\begin{tabular}{|c|c|c|c|}
\hline Product & Ingredients & Label value \% (w/w) & \% Recovery \pm RSD (\%) \\
\hline \multirow{2}{*}{ Leukodermine Ointment } & $p$-Aminobenzoic acid & 2.0 & $101 \pm 0.3$ \\
\cline { 2 - 4 } & Methoxsalen & 0.75 & $99.8 \pm 0.8$ \\
\hline
\end{tabular}

$\mathrm{n}=$ average of 5 analysis.

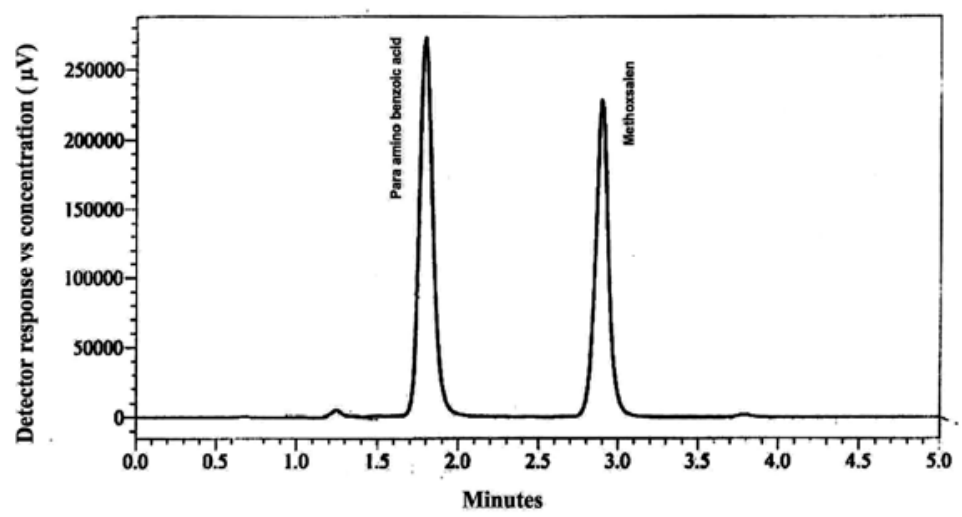

Figure 9. Chromatogram of $p$-aminobenzoic acid and methoxsalen in pharmaceutical ointment.

\section{CONCLUSION}

A new method for the simultaneous estimation of $p$-aminobenzoic acid and methoxsalen in pharmaceutical formulation, and human serum is reported. The described reversed phase HPLC method is very simple, specific, fast and isocratic. The proposed method is suitable and appropriate for routine quality control analysis, stability studies and serum analysis. The developed method is validated using ICH guidelines. The method is very fast and separation is achieved within $5 \mathrm{~min}$. Sample preparation is very simple and is without the use of laborious and expensive solid phase extraction.

\section{ACKNOWLEDGMENTS}

The authors would like to extend their sincere appreciation to the Deanship of Scientific Research at King Saud University for funding through the Research Group Project no RGPVPP-255.

\section{REFERENCES}

1. Reynolds, J.E.F. Martindale, The Extra Pharmacopoeia, 36th ed., Pharmaceutical Press: London; 2009; pp 1605, 1589.

2. Kucova, D.; Maryskova, D.; Davidkova, P.; Gasperic, J. J. Chromatogr. 1993, 614, 340.

3. Susanto, F.; Humfeld, S.; Reinauer, H.; Meschig, R. Chromatographia 1986, 21, 443.

4. Ketchum, C.H.; Robinson Jr, C.A.; Huang, S.T. Clin. Chem. 1990, 36, 1956.

5. Noel, A.G.; Vikas, V.V.; Ashutosh, M.P.; Santosh, S.J.; Avdhoot, M.L.; Snehal, B.; Jayram, A.T. Chromatographia 2009, 69, 1061.

6. Manish, Y.; Pritesh, C.; Vivek, U.; Ajay, G.; Swati, G.; Puran, S.; Sailendra, G.; Pranav, S.S. J. Chromatogr. B 2008, 872, 167.

7. Jyothi, C.D.; Narayana, K.L.; Latha, M.M.; Madhavi, B.; Rambabu, K. Pharmanest 2011, 2, 199. 
RP-HPLC method for simultaneous determination of methoxsalen and $p$-aminobenzoic acid 39

8. Kastel, R.; Rosival, I.; Blahovec, J. Biomed. Chromatogr. 1994, 8, 294.

9. Khan, A.R.; Khan, K.M.; Perveen, S.; Butt, N. J. Pharm. Biomed. Anal. 2002, 29, 723.

10. Evegenev, M.I.; Garmonov, S.Y.; Shakirova, L.S.; Brysaev, A.S. Pharm. Chem. J. 1999, 33, 278.

11. Salvador, A.; Chisvert, A.; Rodriguez, A.; March, J.G. Anal. Chim. Acta 2003, 493, 233.

12. Girish, K.K.; Indrasenan, P. J. Pharm. Biomed. Anal. 1989, 7, 627.

13. Kumar, T.N.; Sreenivasulu, R.; Raju, N.S.V.; Mallu, U.R.; Sandeep, D. Int. J. Sci. Innov. Discov. 2011, 1, 226.

14. Aygun, S.F.; Ozcimder, M. Turk. J. Chem. 1996, 20, 269.

15. ICH Q1A (R2) Guidelines, Stability testing of new drug substances and products, 2003.

16. Razzaq, S.N.; Mariam, I.; Khan, I.U.; Ashfaq, M. J. Liq. Chromat. Rel. Technol. 2012, 35, 651.

17. Razzaq, S.N.; Ashfaq, M.; Khan, I.U.; Mariam, I. Quim Nova 2012, 35, 1216.

18. Razzaq, S.N.; Ashfaq, M.; Khan, I.U.; Mariam, I. Anal. Meth. 2012, 4, 2121.

19. Razzaq, S.N.; Ashfaq, M.; Khan, I.U.; Mariam, I. J. Chil. Chem. Soc. 2012, 57, 1456.

20. Razzaq, S.N.; Ashfaq, M.; Mariam, I.; Khan, I.U.; Razzaq, S.S. Braz. J. Pharm. Sci. 2013, $49,301$.

21. Khan, I.U.; Ashfaq, M.; Razzaq, S.N.; Mariam, I. J. Liq. Chromat. Rel. Technol. 2013, 36, 1437.

22. Ashfaq, M.; Ahmad, H.; Khan, I.U.; Mustafa, G. J. Chil. Chem. Soc. 2013, 58, 2177.

23. Khan, I.U.; Razzaq, S.N.; Mariam, I.; Ashfaq, M.; Razzaq, S.S. Quim Nova 2014, 37, 349.

24. Ashfaq, M.; Akhtar, T.; Mustafa, G.; Danish, M.; Razzaq, S.N.; Nazar, M.F. Braz. J. Pharm. Sci. 2014, 50, 629 .

25. ICH (Q2B) Note for Guidance on Validation of Analytical Procedures: Methodology, International Conference on Harmonization: IFPMA, Geneva; 1996. 